\title{
Academic Freedom in Europe: Time for a Magna Charta?
}

\section{Terence Karran}

Centre for Educational Research and Development, University of Lincoln, Lincoln, LN6 7TS, U.K.

Email: tkarran@lincoln.ac.uk

[This is a post-peer-review, pre-copy edit version of an article to be published in Higher Education Policy in 2009. The definitive publisher-authenticated version 'Academic Freedom in Europe: Time for a Magna Charta?’ Higher Education Policy (2009) Vol. 22, will be available online at: http://www.palgrave-journals.com/hep/index.html]

ABSTRACT: This paper is a preliminary attempt to establish a working definition of academic freedom for the European Union states. The paper details why such a definition is required for the European Union and then examines some of the difficulties of defining academic freedom. By drawing upon experience of the legal difficulties beset by the concept in the USA and building on previous analyses of constitutional and legislative protection for academic freedom, and of legal regulations concerning institutional governance and academic tenure, a working definition of academic freedom is then derived. The resultant definition which, it is suggested, could form the basis for a European Magna Charta Libertatis Academicae, goes beyond traditional discussions of academic freedom by specifying not only the rights inherent in the concept but also its accompanying duties, necessary limitations and safeguards. The paper concludes with proposals for how the definition might be tested and carried forward. KEYWORDS: academic freedom; European Union; working definition.

\section{Introduction}

This paper's purpose is to provide a working definition of academic freedom for the higher education institutions of the European Union. The paper's rationale is as follows. Firstly, academic freedom is considered a fundamental aspect of the workings of Universities in the European Union. For example, the Magna Charta Universitatum declaims: 'Freedom in research and training is the fundamental principle of university life, and governments and universities, each as far as in them lies, must ensure respect for this fundamental requirement' (EUA, 1988, 1). Similarly, the proposed European Union Constitution explicitly states in Article II-73 that '[t]he arts and scientific research shall be free of constraint. Academic freedom shall be respected' (E.U., 2005, 50). The Constitution received insufficient support among the E.U. nations to be enacted into law. However, if the process of integration among 
the 27 (and more) member states is to proceed, a document of similar status is likely to be ratified within the next decade. For such a document to have a meaningful impact in ensuring that academic freedom is nurtured and protected, academic freedom needs to be defined.

Therefore a second rationale is that it is difficult to argue coherently for the importance of academic freedom when it is ill-defined. Hence Jasper $(1990,451)$ states '[o]ne of the primary reasons for the difficulty in protecting academic freedom is that the academic community has agreed upon no single definition of the term'. Similarly, as Felt $(2002,15)$ has recognised, '[e]ven though we would very quickly agree on the importance of "academic freedom" for the development of contemporary societies, the meaning of this notion remains extremely vague', and even when academic freedom is discussed, as Gerber (2001, 23) relates, '[t]oo often, however, references to academic freedom in public discourse are formulaic or disingenuous and fail to take in to account the full meaning of the concept'. Hence, because of its presumed importance, Altbach $(2001,217)$ argues that '[a]cademic freedom needs a universal definition . . . (as) the lack of agreement on the nature of academic freedom makes a common understanding and unified action difficult'.

The final rationale is that Karran's (2007) analysis of the legal protection for academic freedom within the E.U. nations revealed sufficient commonalities to demonstrate that a unified definition is possible, but indicated that the level of academic freedom in some states was markedly lower than in others. For the process of integration among the European Union states to proceed, it is necessary to assess the comparative differences between the nations, and previous empirical research has identified these dissimilarities with respect to academic freedom. Once this is done, benchmarks can be established based on best and most common practice - for example, under Austrian law no member of a university can be required to participate in academic work which conflicts with his/her conscience, and such legislation would produce net benefits for academic freedom if applied across Europe. From such benchmarks appropriate policy mechanisms can be developed, which allocate suitable resources to the individual nations in accordance with the comparative differences identified, to enable all states to reach a similar level of provision. Hence a working definition of academic freedom for the E.U. is an essential step in the development of such policy instruments, to facilitate greater integration of the higher education systems of the European Union nations and the creation of the European Higher Education Learning Space. 


\section{What is Academic Freedom?}

Not surprisingly, academics agree that '[a]cademic freedom is of unquestioned importance' (Stuller, 1998, 342). For example, Turner $(1988,107)$ considers that '[a]cademic freedom is not therefore some arcane and anachronistic privilege. ... It is the simple and basic condition for the job'. Similarly Menand $(1996,4)$ states that academic freedom 'is the key legitimating concept of the entire enterprise'. In consequence of this interest, as Cameron $(1996,1)$ has noted, '[t]he literature on academic freedom is voluminous'. For example, the bibliographic analysis by Sinder (1990) that lists over 170 articles, many of which seek definitional clarity because '[b]efore one can defend academic freedom, however, it must be defined' (Rajagopal, 2003, 25). Given such academic industriousness, Åkerlind and Kayrooz’s (2003, 328) opinion that, '[d]espite the wide ranging debate about academic freedom in recent times, there is little consensus between parties as to what academic freedom actually means. ... the concept is open to a range of interpretations and has been used at times to support conflicting causes and positions', is therefore surprising. However this view is widely shared. For example, from Benson's perspective '[a] precise definition of academic freedom has yet to be articulated' (Benson, 1983, 679), while according to Olivas $(1992,1835)$ ‘'a]cademic freedom ....is poorly understood and ill-defined', an opinion shared by Neave (2002, 332), who reports that 'a single interpretation of Academic Freedom is very far from being shared'.

Hence '[a]cademic freedom seems a simple concept, and in essence it is, but it is also difficult to define' (Altbach, 2001, 206) and '[t]he term is certainly not a self-defining one and can also be a source of considerable contention and even litigation' (Schmeltekoph, 2000, 1). Some of this contention is due to the predilection for argumentation among academics (especially when considering a principle crucial to their profession), some of whom believe that attempts to define academic freedom may be ill-judged. For example, Scott $(1996,177)$ suggests that '[a]cademic freedom can never be boiled down to an essence: it is instead an ethical practice aimed not at the protection of individuals, but at the advancement of our collective well-being'. Similarly, Tierney $(2001,12)$ describes academic life as 'nuanced and complex (such that) one ought not to define academic freedom solely by the presence or absence of overt interference'. Further, Menand $(1996,5)$ refers to the 'more deeply misleading assumption ... that there exists some unproblematic conception of academic freedom that is philosophically coherent and that will conduce to outcomes in particular cases which all parties will feel to be just and equitable'. 
Part of the problem lies in the fact that, as Russell $(1993,1)$ relates, '[t]he words “academic freedom" have often caused confusion because they come from a medieval intellectual tradition which pre-dates most of the current meanings of the word "freedom"'. However, academics have a vested interest in resisting definitional clarity, as when the limits of academic freedom are imprecise it is more difficult for those accused of infringing academic freedom to demonstrate their innocence. As Schmitt $(1975,113)$ points out, the academic freedom campaign was very successful because 'politicians have become very wary of being labelled enemies of freedom for attacking academics. . . The confusions surrounding the concept of academic freedom . . . have been extremely helpful in this campaign'. Moreover, Manan (2000, 255) argues, 'there are professors who used academic freedom as a weapon to defend themselves from their performance being evaluated by the academic community'. Indeed, the degree of elasticity applied to the principle by academics has been inventive, if unpersuasive - Rabban $(1987,1410)$, for example, reports that while he was the AAUP's legal counsel 'several professors of medicine asserted that universities had violated their academic freedom by limiting their clinical income to 100,000 dollars'.

One of the major problems with academic freedom is that, as Van Alstyne $(1975,71)$ notes, '[a]cademic freedom is a "freedom" (i.e., a liberty marked by the absence of restraints or threats against its exercise) rather than a "right" (i.e., an enforceable claim upon the assets of others)'. Consequently, '[a]cademic freedom is most often defined by a violation or an abridgment of a particular right. In other words, academic freedom is often defined by its absence' (Tierney, 2001, 8). Hence, academics in the United States have resorted to legal redress when their academic freedom has been violated. Although the US Supreme Court has upheld the right of academic freedom, Byrne $(1989,257)$ notes that it 'has been far more generous in its praise of academic freedom than in providing a precise analysis of its meaning', such that Lynch $(2003,1066)$ argues '[a]lthough many courts and commentators simply refer to "academic freedom", proper analysis requires further specification of what type of academic freedom is being referenced'.

However US legal rulings have not attempted to define academic freedom, but instead pass opinion on whether it has been infringed. Consequently, as Byrne $(1989,253)$ graphically describes, '[l]acking definition or guiding principle, the doctrine floats in law, picking up decisions as a hull does barnacles'. Hence Byrne $(2001,583)$ argues that academic freedom 'lacks a canonical definition. It primarily is a creation of academics themselves in articulating the normative basis of modern scholarship and teaching. Only derivatively is academic freedom a legal concept.' Most analyses of academic freedom in America relate to 
its protection under the free speech amendments of the US Constitution. Unlike the US Constitution, the proposed European Union constitution categorically states that '[a]cademic freedom shall be respected' (E.U., 2005, 50), but provides no further guidance, suggesting that if the constitution was adopted in this form, the legal wrangles over the definition of academic freedom, evident in the USA, could occur in Europe.

As Goldstein $(1976,1293)$ states, 'the modern development of the doctrine of academic freedom is largely derived from the nineteenth century German concepts of Lehrfreiheit and Lernfreiheit' which are associated with the reforms instituted by Wilhelm von Humboldt at Berlin University. Ash's analysis (2006) challenges the centrality of Humboldt's contribution which, he argues, has acquired a mythical status at variance with historical fact. However, as Nybom (2003, pp.144,141) points out, although '[t]he intellectual core and institutional rational of the Humboldtian university concept rested on ... ideological building blocks which were ...integral dimensions of German idealistic philosophy, and, consequently, not Wilhelm von Humboldt's own original intellectual inventions,' nevertheless the Humboldtian ideal needs to be addressed because of 'its continued presence in almost every European discussion on the mission and future of higher education and research'. Moreover, the Humboldtian model had an equally profound impact in the USA. In 1876, Johns Hopkins was founded as the first American university offering graduate education on the German model. As White (2000, 59) reports: '[o]f the fifty-three Hopkins faculty members when the university was first established, nearly all had studied at German universities. They adopted the German method of instruction, relying on lectures, seminars, and laboratories'. Such was the German influence on Hopkins that, as Hofstadter and Metzger (1955, 377) note: '[a]ptly was this university called the Göttingen at Baltimore', and Johns Hopkins became the model for the modern American research university.

A central aspect of the Humboldtian model was the unity of teaching and research, (Einheit von Lehre und Forschung) and the collaborative pursuit of these by staff and students. Hence Von Humboldt (1970, 242f) considered that universities have 'as their task the cultivation of science and scholarship in the deepest and broadest sense,' in which '[c]ollaboration operates through a process in which the successful intellectual achievements of one person arouse the intellectual passions and enthusiasms of others, and through the fact that what was at first expressed only by one individual becomes a common intellectual possession instead of fading away in isolation.' In this process 'both teacher and student have their justification in the common pursuit of knowledge' and hence 'the goals of science and scholarship are worked towards most effectively through the synthesis of the teacher's and the 
students' dispositions'. Hence as Lay $(2004,48)$ observes '[t]eaching was to be a means of improving both lecturer and student: true knowledge would emerge in the interplay between experience and enthusiasm'.

The Humboldtian model of academic freedom, still resonates, albeit muted, within the universities of the European Union. Thus, in 1988430 University Rectors signed the Magna Charta Universitatum, which proclaimed adherence to the Humboldtian principle that '[t]eaching and research in universities must be inseparable' (EUA, 1998, 1). Despite acknowledging the importance of academic freedom, the Magna Charta Observatory has yet to provide a workable definition of the concept. Work by the International Universities Association led to a 'Recommendation Concerning the Status of Higher Education Teaching Personnel', which was adopted by UNESCO in 1997. The UNESCO (1997) document is comprehensive but has limited utility as the basis for a Magna Charta Libertatis Academicae, or in determining the day to day applicability or repudiation of academic freedom.

\section{Academic Freedom: A Working Definition for the European Union}

There is a danger that any definition will be developed as a lowest common denominator, and cast broad enough to encompass the majority of existing practices in E.U. states. However, for academic freedom to possess more than mere ornamental significance in Europe's Universities, 'the particulars of the concept of academic freedom must be carefully defined; it is not a liberty arbitrarily granted' (Rochford, 2003, 250). However, one must acknowledge that minor variations in university teaching and research occur within and between universities and nation states, which may impact on academic freedom. For example, the dominant university model in Europe is the state funded secular institution but there are both religious and private (non-denominational) universities in the E.U., which operate in a slightly different fashion. In Spain, for example, both private non-denominational and denominational universities exist, however, as Embid (1999, 100) explains all 'Private University recognition Acts refer to the need for a University's organizational and functional rules to "respect and guarantee, fully and effectively, the principle of educational freedom which is shown in academic freedom, freedom of research and freedom of study.”,

Despite such minor exceptions, the longevity of universities and the universality of their structures, (Faculties, Departments), practices (lectures, seminars, theses, etc.) and personnel (Rectors, Professors, Lecturers) are such that a definition of academic freedom (and more significantly, its limitations) should be possible. Moreover, with some justification, Barnett $(1990,137)$ has argued that: '[t]he traditional discussions of academic freedom, ... are also 
depressingly uniform. They frequently exhibit the following characteristics: a lack of specificity; a concern for the academic freedom of staff not students; a defensive proclamation of the rights of academics; and a disinclination to say anything about the duties that should accompany academics' rights'. Hence in attempting a definition, rather than trying to find a conclusive epistemological needle in a philosophical haystack, the concern is to provide a preliminary generic statement that is sharp enough with which to sew together the essential elements of the concept, and make them readily explicable, thereby addressing the deficiencies identified by Barnett. Therefore the following is offered as a preliminary foundation for this definitional process, and a stimulus to debate

The literature on academic freedom concentrates on extolling its desirability, and not defining its limits or accompanying duties. However, as Kennedy (2003, 2) points out: '[a]cademic freedom has a counterpart, academic duty, that is much more seldom used'. Moreover, as Bollinger $(2005,20)$ points out: '[w]e should not accept the argument that our professional norms cannot be defined, and that transgressions thus must be accepted without consequences. ... it will not do simply to say that professional standards are too vague for any enforcement'. Consequently, this paper tries to remedy this by clarifying these limits and duties in greater depth than previous analyses. Hence, as Machlup $(1955,753)$ states: 'If freedom in general is defined as the absence of, or protection from, restraints and interferences, the definition of a particular kind of freedom will have to specify whose protection from whose interferences of what sort and with what kind of activity it refers to'. Some limitations on academic freedom derive from national legal frameworks, others from codes of conduct regarding professional duties, emanating from the weft and warp of academic life. Braxton and Bayer (1999), noting the dearth of empirical research into the norms of university staff, gathered data from circa 1000 respondents, working in a variety of institutions. Seven norms were derived from this data which 'are inviolable because of the extreme severity of the sanctions believed to fit transgressions of such norms' (p. 21), more specifically, tenure removal. Braxton and Bayer accept that their list of norms is not exhaustive, but argue that, on the basis of their sample size, 'the range of incidents . . likely represent the full spectrum of improprieties that might be uncovered' (op. cit, 15).

Rabban $(2001,17)$ points out that academic freedom, has been used to denote 'both the freedom of the academy to pursue its ends without interference from the government . . . and the freedom of the individual teacher (or in some versions - indeed in most cases - the student)'. Consequently Warnock $(1992,120)$ argues, it is necessary to distinguish 'autonomy from academic freedom. ... A great deal of confusion has been generated in recent years by a 
failure to make this distinction'. Wolff's study makes this distinction explicit viz. '[a]cademic freedom is the privilege individual academics may claim as the freedom to question and test received wisdom, to put forward new ideas and controversial or unpopular opinions without placing themselves in jeopardy of losing the jobs or privileges they may have at their institutions. Academic autonomy applies to the institution. It may be defined as the right of academic institutions to decide freely and independently how to perform their tasks' (Wolff, 2000, 198). Hence to avoid confusion, the following definition refers to freedom for individuals within the academy, rather than the freedom of the academy within society, to which the description academic freedom is oft-times applied, but which refers to institutional autonomy (for a fuller discussion, see Finkin 1983, and Hiers 2002).

Similarly, freedom of speech and academic freedom need to be distinguished for, as Olivas $(1993,1838)$ rightly points out, '[t]he concepts of free speech and academic freedom are symmetrical and overlapping, not synonymous'. In the majority of EU states, the distinction between freedom of speech and academic freedom is recognised in law, with the former being protected as a basic constitutional right, while the latter is given separate protection either elsewhere in the constitution or within specific legislation on higher education. Hence this situation is different from that in the United States, where academic freedom is protected derivatively, rather than directly, under the First Amendment to the Constitution which protects freedom of speech. Consequently, as Van Alsytne (1975, 62) notes in the USA 'the phrase (academic freedom) slipped away from a close association with protection of the academic in his professional endeavours and assumed a new synonymy with the general civil liberties of academics.' However, academic freedom is more narrow in focus than freedom of speech and, moreover, unlike freedom of speech, is granted to the few rather than the many. Freedom of speech is a generic activity freedom granted to all who speak and constitutes the absence of constraint on utterances performed for no particular purpose or effect. By contrast, academic freedom is a specific personal freedom granted only to those who 'perform academic actions. Academic actions are teaching, research and the publication of the results of research and reflection' (Shils, 1995, 6), so that these actions can be successfully undertaken.

Academic freedom is granted to academic (non-administrative) teaching and research staff in Universities to enable them to undertake their teaching and research activities to the highest possible professional standards. It comprises the following elements. 


\section{Teaching}

In undertaking their teaching, academic freedom is granted to individual academic staff to determine:

(1) The subject curriculum and how it is taught. In exercising this freedom, staff must ensure that, as agreed by their academic peers and relevant academic associations and professional bodies, the subject content and the method of teaching:

(A) are appropriate for, and relevant to, the subject and level (undergraduate, master, doctoral) at which the course is set and are therefore comparable with (but not necessarily identical to) the content and mode of instruction for similar qualifications at other comparable institutions, and are made known to the students prior to commencement of the course. Any deviations from the course, in respect to the content and method of tuition, must be made known to the students in good time, and the reasons for them reported fully;

(B) accurately and impartially reflect current thinking, recent research and balanced opinion within their subject disciplines and are taught in a mode appropriate to their subject discipline;

(C) are such that they do not introduce any element of positive or negative bias, distortion, misrepresentation or deliberate omission within the content and mode of delivery or make derogatory, stigmatising or irrelevant, oral or written statements (or nonverbal symbols) in respect to (inter alia) age, economic status, ethnicity, gender, language, marital status, nationality, personality, political belief, physical appearance, physical or mental disablement, race, religion, sexual orientation, social status, wealth, etc., unless these relate directly to the subject matter. For example, statements about government military policy would be impermissible during a geology lecture but gender studies’ courses might justifiably include the examination of derogatory statements made about men or women. However, statements about the physical appearance of a particular student or member of staff would never be acceptable.

(2) Who shall be allowed to teach. In exercising this freedom, staff must ensure that:

(A) persons employed to teach are appointed via an open, well documented and transparent selection process (as outlined in the section on tenure), solely on the basis of their teaching and research excellence, expertise and experience and are not subject to any discrimination on the basis of the factors identified in (1) (C). 
(B) notwithstanding point (2) (A), where required by national or state legislation, academic staff may exercise affirmative action to secure employment from groups under-represented in university teaching positions, but this must be undertaken strictly in adherence with the relevant legislation and recorded as such. Such temporary measures must be discontinued when the objectives of equality of opportunity and treatment are achieved.

(3) Who shall be allowed to study. In exercising this freedom, staff must ensure that:

(A) students are chosen solely on the basis of their academic abilities, via an open, well documented and transparent selection process, and without discrimination on the basis of any other irrelevant criteria [as identified in (1) (C), above].

(B) notwithstanding point (3) (A), where required by national or state legislation, academic staff may exercise affirmative action to secure entry for students from groups normally under-represented in higher education, but this must be undertaken strictly in adherence with the relevant legislation and recorded as such. Such temporary measures must be discontinued when the objectives of equality of opportunity and treatment are achieved.

(4) How students' achievements shall be assessed and graded. In exercising this freedom, individually and collectively, academic staff must ensure that, as agreed by their academic peers and relevant academic associations and professional bodies:

(A) the methods of assessment and of calculating grades are appropriate for the subject curriculum and level (undergraduate, master, doctoral) at which the course is set and are comparable with those used for similar qualifications at other comparable institutions, and are made known to the students at the commencement of the course. Any deviations to the assessment mode during the course, must be made known to the students in good time, and the reasons for them reported fully;

(B) the assessment marks and grades awarded relate directly to the academic ability of students, as demonstrated via their performance of assessment tasks, and without reference to any other irrelevant criteria [as identified in (1) (C), above]. To avoid implicit or explicit bias in assessment and grading, the university should attempt to anonymise the assessment and grading processes and institute a system of double blind marking;

(C) students are provided with concise and timely feedback on assessment performance and grades, which enables a full understanding of the rationale for the grade awarded; 
(D) a national or institutional system of quality assurance exists whereby external examiners, qualified in the subject, can evaluate the assessment and grading systems to ensure that, in accordance with national and subject specific norms, they are appropriate, relevant, accurately, consistently and fairly applied, and free from bias;

(E) institutional and external appeals systems exist, whereby students can seek a second opinion on a grade awarded, if they believe that the grade awarded does not accurately reflect the standard of their work, in respect to a specific assessment task.

(5) Whether they are speaking in their capacity as a teacher or a citizen. Academic freedom is freedom of speech given for expert utterance within the university, in pursuit of teaching and research excellence. Hence, faculty staff engaging in extra-mural utterances are not protected by academic freedom, but enjoy all other constitutional and legal freedoms afforded to the population at large. Moreover, in making utterances as private citizens, faculty staff must make it explicit that they are neither speaking nor acting for their institutions. Similarly, utterances made on campus which are outside the academics' stated areas of expertise (for example, their beliefs on religion or politics), or made outside a formal academic setting, are protected by generic rights of free speech, but not by academic freedom, and faculty making such utterances have a responsibility to distinguish when their objective is advocacy rather than academic excellence. Furthermore, on-campus utterances, undertaken by external invited speakers, as part of the process of formal scholarly debate, have the protection of academic freedom, and the right to be heard.

\section{Research}

In undertaking research, academic freedom is granted to academic staff to determine:

(1) In which subject areas they focus their research efforts, and the research methods they adopt. In exercising these freedoms, staff must ensure that, as agreed by, their academic peers, relevant academic associations and professional bodies, and national and international governmental bodies:

(A) their research does not contravene international and national laws, and institutional codes of ethical principles and practices, working conditions and regulations, specific to their academic discipline and the subject(s) chosen for research (for example the collection and use of human tissue in genetic research requires prior informed consent); 
(B) their research does not contravene generic international and national laws, and institutional codes of ethical principles and practices, working conditions and regulations, in relation to financial control and audit, personnel management, the anonymisation, collection, disclosure, disposal, protection, and storage of sensitive and personal data, the maintenance of workplace health and safety, the management of risk to research workers, participants and third parties, the registration of IPR, etc.;

(C) persons employed for research are appointed, via an open, well documented and transparent selection process, solely on the basis of their research excellence, expertise and experience and are not subject to discrimination on the basis of the factors identified above;

(D) notwithstanding point (C) above, where required by national or state legislation, academic staff may exercise affirmative action to secure employment for groups under-represented in research positions in universities, but this must be undertaken strictly in adherence with the relevant legislation and recorded as such. Such temporary measures must discontinued when the objectives of equality of opportunity and treatment are achieved.

(E) where research is undertaken by using financial and other resources from an external agency (either private or public), the requirements and conditions of any sponsoring agency must be clearly established and expressed in a mutually agreed contract or equivalent document. More particularly, there must be no undeclared conflict of interest (academic, financial or personal in nature) in the proposed research and the relative rights of the research sponsors and researchers over research outputs (respecting the ownership, publication and subsequent use and exploitation of research data) must be made clear. Progress on sponsored research must be provided accurately and regularly, and any deviations to the contract (e.g., delay, early completion or termination, re-definition, etc.), and the reasons for them reported fully.

(F) national and institutional systems of quality assurance exist to ensure that all research applications are scrutinised and have prior ethical approval, and to investigate complaints and expressions of concern about breaches of ethical procedures, whereby such breaches can be investigated and appropriate actions taken.

(2) With whom and for what purpose they pursue their research. No member of a university may be required to participate in academic or artistic work which conflicts with his/her conscience. 
(3) The methods and avenues by which they disseminate, make accessible, exploit and commercialise the findings of their research. In exercising this freedom, staff must ensure that, as agreed by their academic peers and relevant academic associations and professional bodies, their research outputs:

(A) accurately and honestly report the full results of their research and are not subject to plagiarism, forgery, misleading manipulation or partial reporting of research data and results;

(B) acknowledge fully and fairly the relative direct and indirect contributions of co- and joint authors, academic colleagues and other people and organisations (including sponsors) involved in the research;

(C) do not compromise the anonymity of research participants, co-researchers and sponsoring bodies, breach personal or institutional confidentiality, or infringe intellectual property rights agreements.

Few in European academia would gainsay the previous statements, variations of which appear within national and institutional pronouncements on academic freedom and to which, Arblaster maintains, '[e]very vice-chancellor, college principal and education minister pays verbal tribute' (Arblaster, 1974, 10). However, such declarations constitute just the bare bones of academic freedom. The vital flesh that covers them, and gives operational sustenance to the concept in both the intellectual spirit and the day to day minutiae of university life, lies in the norms and procedures of shared governance and tenured employment which are, as Gerber maintains, 'the two principal institutional bulwarks for academic freedom' (Gerber, 2001, 22). Previous research by Karran (2007) into the laws on academic tenure revealed variations between the different EU states, but showed, categorically that some form of tenure (sometimes via competition and/or with a limited term) is the norm rather than the exception. Hence, for a working, rather than merely postulatory, definition of academic freedom for the European states, these must be addressed.

\section{Self Governance}

To guarantee academic freedom, academic staff must:

(1) Have the right to voice opinions on the educational policies and priorities within their institutions without the imposition or threat of punitive action, and fulfill their collegial obligations in a professional manner. In exercising this freedom, staff must ensure that:

(A) all staff have an equal right to speak and their opinions and beliefs are accorded due respect; 
(B) all personal, departmental and institutional professional commitments are fulfilled in a timely and professional manner.

(2) Have the determinant voice and prominent role in decision making processes. How this is achieved will differ with national and institutional variations in the decision making structures of universities. In universities where the Senate, comprising the academic teaching staff, is the sole deliberative and executive body, decisions will, perforce, require the support of the majority of academic staff. In universities in which the Senate also includes representatives of students, and research and nonacademic staff, or in which executive powers are shared between the Senate and one or more internal or external bodies, protocols must exist ensuring that the voices of the academic staff are primus inter pares, and guarding against filibustering, policy gridlock and professorial oligarchy. For example, by giving 60 out of 100 Senate seats to academic staff, but applying a threshold of 70 votes for an ordinance to be enacted, the academic staff have the major say in decision making, but cannot ignore the opinions of other participating groups. Where policies are determined following due democratic process, staff are professionally obligated to assist in their implementation, even though personally they may disagree with the policies.

(3) Be able to appoint, from amongst their number, people into positions of managerial authority, and hold them to periodic account by agreed democratic processes. However, in exercising these powers academic staff:

(A) where required by national or state legislation, or institutional guidelines, may exercise affirmative action to secure entry to managerial positions from groups under-represented in such positions in universities, but this must be undertaken strictly in adherence with the relevant legislation and guidance and recorded as such. Such temporary measures must be discontinued when the objectives of equality of opportunity and treatment are achieved.

(B) should ensure that the burden of administration does not repeatedly fall on the same individual(s) and/or departments, by limiting the number of consecutive terms an individual can spend in a particular post, and rotating the posts between departments.

(4) Be able to determine who shall serve as Rector. Where possible the Rector should be appointed from within the University by democratic process with the support of the majority of academic staff, and subjected to the same democratic process if additional terms of office are sought by an incumbent Rector. There should be a limit to the number of consecutive terms an individual can serve. Where the appointment is external (owing 
to a dearth of suitable internal candidates, or because of national or state legislation), the academic staff should have the major role in determining the appointment. The form of this role will vary between institutions and countries but could include determining the short list of candidates, voting to choose one from a shortlist of candidates drawn up externally, having the right of veto of an externally selected candidate. As with other governance procedures, the aim is to encourage active participation whilst preventing professorial obstinacy and capriciousness.

\section{Tenure}

Tenure is granted to academics so that they can undertake their teaching and research duties to the highest levels of professional competence. Tenure gives academics the freedom to undertake research which questions accepted knowledge, via avant-garde ideas and controversial theories, which are then tested in the crucible of expert critical debate with students and staff, without fear of reprisal. The corollary of this is that those academics who cease to perform their duties in an active, competent and professional manner neither need, nor merit, the protection of tenure. Defining adequate cause for dismissal is, therefore, as necessary an element of academic freedom as the granting of tenure.

Hence, to guarantee and protect the integrity of academic freedom, contractual arrangements must exist ensuring that only academic staff with the requisite high level of competence in research and teaching are given protection from the fear of dismissal for the views they express; and enable action to be taken, through due process, to remove tenure from staff who fail to meet minimum levels of competence or professional standards of conduct in these areas, or for whom, because of bona fide circumstances (programme viability and institutional financial exigency), the university is unable to continue to offer employment. These processes are different in nature. In the first it is incumbent upon the probationer to demonstrate competence, in the second it is incumbent on the institution to demonstrate due cause. However, the process whereby tenure is removed should be as stringent and rigorous as that whereby it is awarded. To uphold the integrity of academic freedom, faculty members must just as willing and empowered to recommend the revocation of tenure and the dismissal of a faculty member for just cause, as they are to recommend the granting of tenure for staff that meet the necessarily high probationary standards. How these processes operate will differ in accordance with national, federal and state variations in generic employment law and the contractual arrangements and obligations of individual higher education institutions. At the very least any system should ensure that: 
(1) The terms and conditions of every appointment are supplied, in writing, to each staff member on appointment (as are any subsequent revisions to that appointment). Any limitations on academic freedom resulting from the distinct nature of the institution (e.g. if it has specific religious beliefs), should be clearly stated. Additionally, a full explanation of the procedures for the approval and revocation of tenure should be clearly documented.

(2) There is a statutory probationary period of employment:

(A) During which staff have the full protection of academic freedom enjoyed by all other academic staff.

(B) Which is of finite length (typically between five to seven years and which may be served at more than one institution), sufficient to enable assessment of the candidates' professional expertise and commitment.

(C) During which the peer review process has the ability to exclude all those who demonstrably cannot meet the requisite professional standards in respect to their teaching and research responsibilities.

(D) At an agreed date before the end of which, probationary staff should be subjected to an agreed peer review procedure, (see (4) below) which determines whether they are offered continued employment in a tenured position, or whether their employment ceases at the end of the probationary period, and probationers should be informed of the outcome in writing and may request the reasons which contributed to the decision.

(3) Prior to the start of the probationary period, the procedures of the tenure process are clearly stated in writing, including a full explanation of, e.g., minimum requirements in terms of the provision of lectures and tutorials and the production of published research outputs, details of the internal system of peer review, etc. The relative weights applied to these activities must be made known to the candidate at the start of the probationary period.

(4) There is a rigorous peer review system for assessing whether staff are granted tenure at the end of their probationary period and as a part of which:

(A) staff provide a portfolio describing their work during their probationary period. Such a portfolio is likely to include information on the following:

(i) Teaching: lectures and seminars (at undergraduate and postgraduate levels), and, if appropriate, peer and student evaluations of teaching competence; 
(ii) Research activities including successful grant applications, published outputs (whether in print, accepted for publication or submitted for publication), creative artefacts, other scholarly efforts and $\mathrm{PhD}$ supervision;

(iii) Pastoral care and other services for students;

(iv) Managerial and administrative duties and service on committees, within the university;

(v) Public service for the community at local, state or national level;

(vi) Other evidence of scholarly merit or academic recognition, such as fellowships, honors, and election to office in scholarly or professional organisations.

(vii)The names of possible external reviewers, of a rank higher than the candidate, and able to make informed judgements as to the candidate's academic merit.

(B) The candidate's Head of Department, after consultation by an agreed process with colleagues of a rank higher than the candidate, submits the names of external evaluators able to make informed judgements as to the candidate's academic merit.

(C) An institutional Tenure Review Committee is established which

(i) comprises members, none of whom are known, personally or academically to the candidate, of a rank higher than the candidate, chosen by democratic selection from among the Faculty on the basis of their objectivity and competence, to serve for a set period, and which elects its own Chair..

(ii) reviews the submissions from the candidate and the Departmental Head and selects from them an agreed number of external reviewers, from whom it solicits an appraisal of the candidate's merit, based on a critical review of the candidate's portfolio of achievement. Evaluators may also be asked to comment on other aspects of the candidate's case of which they may have specific familiarity, such as papers heard delivered at conferences. Institutional guidelines about the nature of the review process must be provided to reviewers who must judge the candidate purely on the basis of competence, rather than any substantive viewpoints the candidate may have expressed, and without reference to any other of the candidate's attributes which are deemed irrelevant. To encourage objective and unequivocal evaluations, the external reviewers must be assured that their statements will be confidential.

(iii) deliberates in camera to consider, by an agreed process of free debate, the evaluation of the candidate's merit as expressed by the external reviewers, and makes a recommendation as to whether the candidate should be offered tenure. 
(5) There is a rigorous system of assessing whether tenure should be terminated because of lack of programme viability, as a part of which

(A) An institutional Committee is established which

(i) comprises members, none of whom are known, personally or academically to the affected staff, chosen by democratic selection from among the Faculty on the basis of their objectivity and competence, to serve for a set period, but which does not include staff whose jobs are at risk through the termination of the programme, and which elects its own Chair.

(ii) reviews the decision to formally cease a program of instruction, ensuring that such a decision is based on a comprehensive appraisal of the likely long term impact on the institution of continuing or discontinuing with the programme.

(iii) recommends either continuing or discontinuing the relevant programme.

(vi) hears appeals from affected staff against their relocation to comparable posts and/or job termination following a decision to discontinue a programme.

(B) Every effort is made by the institution to provide affected staff with comparable employment elsewhere in the institution, including the provision of additional retraining.

(C) Where a tenured post is removed, it should not be filled within agreed period of time, without first offering it to the previous post-holder. The tenured employment of a faculty member will not be terminated in favor of retaining a faculty member without tenure, except in extraordinary circumstances, the reasons for which must be welldocumented.

(6) There is a rigorous system of assessing whether tenure shall be terminated because of institutional financial exigency as a part of which:

(A) An institutional Committee is established which:

(i) is composed of members, none of whom are known, personally or academically to the affected staff, chosen by democratic selection from among the Faculty on the basis of their objectivity and competence, to serve for a set period, but which does not include staff whose jobs are at risk through institutional financial exigency, and which elects its own Chair.

(ii) establishes whether a situation of bon fide financial exigency exists, or is likely to exist, of such a magnitude (for example, inability to meet operating expenses) that it constitutes a threat to the continued survival of the institution and cannot be remedied by any other means. 
(ii) determines what actions need to be taken to alleviate the situation.

(iii) sets the criteria for identifying the staff whose tenure shall be removed, and applies them.

(vi) ensures that all possible alternatives to the termination of tenure among the staff thus identified (such as transfers and re-training) have been exhausted.

(B) Where a tenured post is removed, it shall not be filled within agreed period of time, without first offering it to the previous post-holder.

(7) There is a rigorous system of assessing whether tenure shall be revoked and employment terminated because of just cause (that is, for reasons other than lack of programme viability or institutional financial exigency). At the very least any system should ensure that

(A) A full written explanation of the grounds and procedures for the revocation of tenure is supplied to each staff member on appointment. The grounds that are deemed valid may vary between different nations and universities, in accordance with the differing degrees of importance that are attached (through individual institutional customs and practices) to the various elements of the academic role. However, these are likely to include unlawful activities (e.g. theft of funds or property), abuse of the constituent elements of academic freedom identified above, repeated and systematic failure to fulfill academic duties (e.g. in the areas of teaching and research) to the minimum standards required to merit the protection of academic freedom afforded by the original granting of tenure, and of the following violations of institutional and professional norms (as identified by Braxton and Bayer 1999, 21-38):

(i) Moral Turpitude - depraved, unprincipled acts by faculty members (e.g. sexual relationships with a student, making suggestive sexual comments to a student, intoxication by dint of consumption of alcohol or drugs).

(ii) Particularistic Grading - the uneven or preferential treatment of students in the determining of grades (e.g. differential application of policies about late submission of assessments).

(iii) Condescending Negativism - the treatment of both colleagues and students in a condescending and demeaning way (e.g. criticising a colleague's work in front of students).

(iv) Inattentive Planning - a lack of attention to the planning of a course (e.g. failing to provide a syllabus for students before commencing a course). 
(v) Personal Disregard - failure to address the needs and sensitivities of students as individuals (e.g. habitually arriving late to classes and finishing them early).

(vi) Uncommunicated Course Details - failure to inform students of important particulars about a course (e.g. changes in class and examination times and locations without due notice).

(vii)Uncooperative Cynicism - inveterate refusal to participate actively in legitimately assigned departmental duties as part of the role of university teaching (e.g. persistent absence from departmental management meetings, contemptuous neglect of teaching duties).

Procedural standards for the conduct of tenure revocation and staff dismissal hearings may vary in accordance with national employment law and institutional statutes, but are likely to include the appellant's right

(i) not to request a hearing, provided that the appropriate bodies are informed in writing, within a specified period prior to the hearing.

(ii) for sufficient time to prepare a defence.

(iii) to request that the hearing is held in private, not in public.

(iv) to appoint an external advocate to assist in the preparation and presentation of written and oral defence evidence.

(v) of access to all institutional documents, relevant to the case.

(vi) to call witnesses (from within the university and from other universities) to attend the hearing and give evidence, on the appellant's behalf.

(vii)to question, either in person or via an external advocate, all witnesses at the hearing who testify orally.

(viii) to address, either in person or via an external advocate, all written evidence considered at the hearing, including witness statements.

(B) An institutional Tenure Review Committee (either a Standing Committee, or one especially convened) is established:

(i) which is composed of members, none of whom are known, personally or academically to the appellant, chosen by democratic selection from among the Faculty on the basis of their objectivity and competence, to serve for a set period, and which elects its own Chair.

(ii) which undertakes a confidential, informal assessment as to whether there are reasonable grounds to question the fitness of a faculty member who has tenure or whose period of appointment has not expired, and establishes whether formal 
proceedings to consider revocation of tenure and subsequent dismissal should be initiated.

(iii) which determines whether formal proceedings are warranted. If they are, the committee should:

(a) issue a formal written statement to the person concerned, specifying the grounds for the revocation of tenure to be considered at an evidential hearing;

(b) indicate the date, time and location of the evidential hearing, undertaken by the relevant university committee, to determine the veracity of the grounds for the revocation of tenure;

(c) request a written response, within a specified time period, indicating whether the appellant wishes the hearing to go ahead, and if so, petition a written response in rebuttal of the stated grounds;

(d) clarify and inform the appellant of his/her procedural rights;

(e) assign an appropriately qualified administrator to gather and present supportive evidence for the grounds of tenure revocation.

(iv) that meets at the due date and deliberates upon the statement of grounds for dismissal and the written rebuttal provided by the appellant. If the appellant has determined not to have a hearing, and has therefore provided no rebuttal, the Committee should adjudicate on the basis of the available evidence, and determine whether tenure should be revoked. If the appellant opts to have a hearing, it is the duty of the Committee to:

(a) examine the grounds for tenure revocation and the appellant's rebuttal.

(b) assess the veracity of these statements, by reference to written evidence and via the questioning of witnesses by the Committee, the appellant or his advocate, and the administrator appointed to gather supportive evidence for tenure revocation.

(c) hear oral arguments advanced by the appellant or his advocate, and the administrator appointed to gather supportive evidence for tenure revocation.

(d) provide definitive verdicts, stating whether each of the grounds cited for the revocation of tenure is upheld or denied;

(e) issue a conclusive report, on the basis of the verdicts reached, to either revoke or retain tenure for the appellant.

(8) There is an Appeals System under whichxxx 
(A) unsuccessful candidates can appeal against:

(i) tenure denial on the grounds of negligent process or inadequate consideration;

(ii) tenure revocation on the grounds of programme non-viability:

(iii) tenure revocation on the grounds of institutional financial exigency:

(iv) tenure revocation on the grounds of just cause, for reasons other than programme non-viability or institutional financial exigency.

(B) an Appeals Committee is established, composed of members, chosen on the basis of their objectivity and competence by a process of democratic selection from among the Faculty, to serve for a set period and which elects its own Chair. None of committee must be known, personally or academically to the appellant, and in the cases examining tenure denial decisions, they must be of a rank higher than the appellant. In the case of tenure revocation for just cause, the Appeals Committee will be drawn from the University’s Governing Body.

(C) the Appeals Committee assesses, in camera, whether the Tenure Review Committee followed due processes, in line with national or state legislation and the relevant statutes and standards of the institution, when:

(i) evaluating a candidate's case for tenure approval,. The Appeals Committee cannot reverse a tenure denial decision, but may request reconsideration by the Tenure Review Committee, indicating the areas in which it believes the process was negligent or the consideration inadequate.

(ii) evaluating the case for tenure revocation on the grounds of programme nonviability. The Committee may request reconsideration of the grounds for programme non-viability and hear appeals from affected staff against their relocation to comparable posts and/or job termination following a decision to discontinue a programme.

(iii) evaluating the case for tenure revocation on the grounds of financial exigency. The Committee may request reassessment as to whether a state of financial exigency exists, or of the criteria used to identify staff at risk, or of the application of those criteria.

(iv) evaluating the case for tenure revocation on the grounds of just cause. The Committee may request reconsideration, indicating the respects in which it believes the process was negligent, the consideration inadequate, or the outcome unjust in the light of new evidence. 
(C) the Appeals Committee provides copies of its deliberations, indicating the reasons for either upholding or denying the appeal, to the appellants, the designated university administrative officer and the Tenure Review Committee which, if requested, will be re-constituted to examine new evidence, ameliorate assumed negligent or inadequate practice in its deliberations, and produce a report of its deliberations for consideration by the Appeals Committee. The decision of the Appeals Committee is final.

(D) if the Appeals Committee requests reconsideration by the Tenure Review Committee, it assesses the report arising from the reconsideration, and makes a final decision, indicating the reasons for either upholding or denying the appeal, to the appellants, the designated university administrative officer and the Tenure Review Committee.

\section{Conclusion and Next Steps}

This paper's major rationale was to answer the criticisms of Barnett $(1990,137)$ and others, by moving beyond the usual formulaic approaches which suggest that academic freedom is important but is so finely nuanced, historically specific, etc. that definitions are not only impossible, but should not even be attempted. Additionally, there was a desire to respond to a long standing call for an authoritative canon stipulating not only the rights of academic freedom but also its limitations, thereby providing a practical modus vivendi for the concept within today's studia generalia. Nearly forty years ago Lord Ashby, then Cambridge’s Vice Chancellor, echoing Humboldt's principles, described the distinctive feature of a university as 'the essential relevance of research to teaching', but lamented that the academic profession had no declared ethical code and therefore called for a Hippocratic Oath for higher education which could 'stabilise ... a schizophrenic and disintegrating profession and ... provide a basis of leadership, authority and example to students' (Ashby, 1969, pp 64, 66) which idea has recently been given greater clarity and support by Watson (2007). Similarly, Thorens (2000, 281) has argued that 'academic freedom and university autonomy are necessary, that a universal charter on them is also necessary. Indeed, all previous documents - some of great value - which have been written in the last few decades are either local or regional, as far as their origin goes. Or they concern one type of institution. Or again, they are very general and mix up academic freedom and other concepts. A universal charter is therefore desirable'. Following from Thorens' exhortation, the European Union already has a Magna Charta Universitatum, establishing a Magna Charta Libertatis Academicae, constitutes a desirable 
next step. Such a document would protect the professional rights of staff, and raise vocational standards, whilst providing enhanced protection for students from abuses of academic freedom.

To take this work forward, requires that this preliminary definition, like all academic research that attempts to advance knowledge, is tempered and tested within the crucible of informed and rigorous academic debate. Most of the elements of this working definition are derived from, and relate to, common strands of national legislation on academic freedom within the EU states, however, questions that could usefully be addressed include the following. To what extent, and in what ways, does this definition contradict the constitutions and laws of the European Union and its constituent states? To what extent does it infringe the academic freedom of students? What support would there be within the academic staff of Europe's universities to implement such a definition? How similar/different is it from national legislation on employment protection? Would implementing such a definition lead to a reduction in academic freedom in some states? Would implementing such a definition strengthen the European Higher Education Learning Space? How readily could such a definition be incorporated into the European Revision Treaty, or an academic Bill of Rights? More importantly, would it be necessary to have a supra-national authority to which appeals could be made to ensure that the requirements of any such Magna Charta are upheld?

Further work on refining the concept of academic freedom is both timely and necessary. For example, following Barnett's suggestion, 'a theory of academic freedom which does justice to the actual relationship between higher education and society rather than an imaginary relationship’ (Barnett, 1988, 90), would do much to strengthen and protect the concept. Similarly, little empirical work has been undertaken on how academic staff understand, experience, and make use of their academic freedom in European universities, or whether and what types of academic freedoms could (and should) be afforded to students. More important than this, however, is a recognition by academics that the protection of academic freedom is something in which they should become actively involved. There is a tendency, given both the ever growing pressures to teach more students and write more articles, for university staff to ignore the process whereby, via legislation or legerdemain, academic freedom is being slowly but irrevocably eroded. Academic freedom brings rights and responsibilities - a major one of which is ensuring that such rights are there to be used and enjoyed by future generations of scholars. Society at large will only sanction the granting of particular freedoms to a specific professional group, if it is persuaded that these freedoms produce net benefits. Hence it is incumbent on today's academics to voice, with passion and 
persuasion, the reasons for the continuance of academic freedom. Neglecting such a responsibility will surely impoverish academics, academia, and the free society in which they operate. 


\section{References}

Åkerlind, G. and Kayrooz, C. (2003) 'Understanding academic freedom: the views of social scientists’, Higher Research and Development 22(3): 327-344.

Altbach, P. (2001) 'Academic freedom: International realities and challenges', Higher Education 41(1/2): 205-219.

Arblaster, A. (1974) Academic Freedom, Harmsworth: Penguin.

Ash, M. (2006) 'Bachelor of What, Master of Whom? The Humboldt Myth and Historical Transformations of Higher Education in German-Speaking Europe and the US', European Journal of Education 41(2): 245-267.

Ashby, E. (1969) ‘A Hippocratic Oath for the Academic Profession’, Minerva 8(1): 64-66

Barnett, R. (1988) 'Limits to Academic Freedom: Imposed-Upon or Self-Imposed?' in M.

Tight (ed.) Academic Freedom and Responsibility, Buckingham: SRHE/OU Press, pp. 88103.

Barnett, R. (1990) The Idea of Higher Education, Buckingham: SRHE/Open University Press.

Benson, D. (1983) 'Tenure Rights In Higher Education In The Face Of Financial Exigency: The Impact Of Private Agreement, Collective Bargaining', Detroit College of Law Review 3(3): 679-707.

Bollinger, L. (2005) 'The Value and Responsibilities of Academic Freedom', The Chronicle of Higher Education 51(31): B20.

Braxton, J. and Bayer, A. (1999) Faculty Misconduct in Collegiate Teaching, Baltimore: Johns Hopkins University Press.

Byrne, P. (1989) ‘Academic Freedom: A Special Concern of the First Amendment', Yale Law Review 99(2): 251-340.

Byrne, P. (2001) 'Academic Freedom Of Part-Time Staff', Journal of College and University Law 27(3): 583-593.

Cameron, D. (1996) 'Academic Freedom and the Canadian University’, AUCC Research File 1(3): $1-12$.

Embid, A. (1999) 'The Legal Framework of Private Universities in Spain', European Journal for Education Law and Policy, 3: 89-109

European Union. (2005) Constitution Of The European Union, Luxembourg: Office for Official Publications of the European Communities.

European Universities Association. (1988) Magna Charta Universitatum, Bologna: EUA. 
Felt, U. (2002) University Autonomy In Europe: Changing Paradigms In Higher Education Policy (Proceedings of the Seminar of the Magna Charta Observatory), Bologna: Bononia University Press.

Finkin, M. (1983) ‘On “Institutional” Academic Freedom’, Texas Law Review 61(5): 817857.

Gerber, L. (2001) “"Inextricably Linked”: Shared Governance and Academic Freedom’, Academe 87(3): 22-24.

Goldstein, S. (1976) 'The Asserted Constitutional Right of Public School Teachers to Determine What They Teach', University of Pennsylvania Law Review 124(6): 1293-1357.

Hiers, R. (2002) 'Institutional Academic Freedom vs. Faculty Academic Freedom In Public Colleges And Universities: A Dubious Dichotomy', Journal of College and University Law 29(1): 35-109.

Hofstadter, R. and Metzger, W. (1955) The Development Of Academic Freedom In The United States, New York: Columbia University Press.

Human Rights Watch (Undated) Academic Freedom: Thematic Research and Reports. http://www.hrw.org/advocacy/academic/afp5.htm,last accessed 11 July 2007.

Jasper, S. (1990) 'Britain's Education Reform Act: A Lesson in Academic Freedom and Tenure’, Journal of College and University Law 16(3): 449-496.

Karran, T. (2007) 'Academic Freedom in Europe: A Preliminary Comparative Analysis', Higher Education Policy 20(3): 289-313.

Kennedy, D. (2003) Academic Duty, Cambridge: Harvard University Press

Lay, P. (2004) The Interpretation of the Magna Charta Universitatum and its Principles, Bologna: Bononia University Press.

Lynch, R. (2003) 'Pawns of the State or Priests of Democracy? Analysing Professors' Academic Freedom Rights Within the State’s Managerial Realm', California Law Review 91(4): 1061-1108.

Machlup, F. (1955) 'Some Misconceptions Concerning Academic Freedom’, AAUP Bulletin 41(4): 753-784.

Manan, W. (2000) 'Academic Freedom: Ethical Implications and Civic Responsibilities’, in G. Neave (ed.) The Universities' Responsibilities to Society: International Perspectives, Kidlington: Elsevier Science, pp. 253-270.

Menand, L. (1996) 'The Limits of Academic Freedom', in L. Menand (ed) The Future of Academic Freedom, Chicago: University of Chicago Press, pp. 1-20. 
Neave, G. (2002) ‘Academic Freedom in an Age of Globalisation', Higher Education Policy 15(4): 331-35.

Nybom, T. (2003) 'The Humboldt Legacy: Reflections on the Past, Present, and Future of the European University’, Higher Education Policy 16(2): 141-159.

Olivas, M. (1993) 'Reflections of Professorial Academic Freedom: Second Thoughts on the Third “Essential Freedom”', Stanford Law Review 45(6): 1835-1858.

Rabban, D. (1987) 'Does Academic Freedom Limit Faculty Autonomy?’, Texas Law Review 66(7): 1405-1430.

Rabban, D. (2001) 'Academic Freedom, Individual or Institutional?’, Academe 87(6): 16-20.

Rajagopal, B. (2003) ‘Academic Freedom as a Human Right’, Academe 89(3): 25-28.

Rochford, F. (2003) 'Academic freedom as insubordination: the legalisation of the academy', Education and the Law 15(4): 249-262.

Russell, C. (1993) Academic Freedom, London: Routledge.

Schmeltekoph, D. (2000) 'Whence Academic Freedom?', Centre for the Study of Ethics, Conference on Academic Freedom, Utah Valley State College, February $11^{\text {th }} 2000$.

Schmitt, R. (1975) 'Academic Freedom: The Future of a Confusion', in E. Pincoffs (ed) The Concept of Academic Freedom, Austin: University of Texas, pp. 110-124.

Scott, J. (1996) 'Academic Freedom as an Ethical Practice', in L. Menand (ed) The Future of Academic Freedom, Chicago: University of Chicago Press, pp.163-186.

Shils, E. (1995) ‘Academic Freedom and Permanent Tenure’, Minerva 33(1): 5-17.

Sinder, J. (1990) 'Academic Freedom: A Bibliography', Law and Contemporary Problems 53(5): 381-392.

Stuller, W. (1998) 'High School Academic Freedom: The Evolution of a Fish Out of Water', Nebraska Law Review 77(2): 301-343.

Thorens, J. (2000) 'Proposal for an International Declaration on Academic Freedom and University Autonomy', in G. Neave (ed) The Universities' Responsibilities to Society: International Perspectives, Oxford: Elsevier Science, pp. 271-282.

Tierney, W. (2001) ‘Academic Freedom and Organisational Identity’, Australian Universities Review 44(1): 7-14.

Turner, J. (1988) 'The Price of Freedom', in M. Tight (ed) Academic Freedom and Responsibility, Buckingham: SRHE/OU Press, pp. 104-113.

UNESCO, (1997) Recommendation concerning the Status of Higher-Education Teaching Personnel. Records of the General Conference, Twenty-ninth Session, 21 October to 12 November 1997, Volume 1 Resolutions, Paris: UNESCO, pp.26-36. 
Van Alstyne, W. (1975) 'The Specific Theory of Academic Freedom and the General Issue of Civil Liberty', in E. Pincoffs (ed) The Concept of Academic Freedom, Austin: University of Texas, pp. 59-85.

Von Humboldt, W. (1970) 'On the Spirit and Organisational Framework of Intellectual Institutions in Berlin', Minerva 8(2): 242-250 [English translation of original manuscript: 'Uber die innere und äussere Organisation der höheren wissenschaftlichen Anstalten zu Berlin', (1903) Gesammelte Schriften, Herausgegeben yon der Königlich Preussischen Akademie tier Wissenschaften, Berlin: B. Behr's Verlag].

Warnock, M. (1992) 'Higher education: The concept of autonomy', Oxford Review of Education 18(2): 119-124.

Watson, D. (2007) 'Does Higher Education Need a Hippocratic Oath?', Higher Education Quarterly 61(3): 362-374.

White, L. (2000) 'Academic Tenure: Its Historical And Legal Meanings In The United States And Its Relationship To The Compensation Of Medical School Faculty Members', Saint Louis University Law Journal 44(1): 51-80.

Wolff, K. (2000) 'Academic Freedom and University Autonomy', in G. Neave (ed) The Universities' Responsibilities to Society: International Perspectives, Oxford: Elsevier Science, pp. 196-205. 